\title{
The meanings and techniques of lighting in the car service
}

\author{
Olga Petrunya \\ Kyiv National University of Construction and Architecture \\ Povitroflotsky avenue 31, Kyiv, Ukraine, 03037 \\ olga_petrunya@ukr.net, orcid.org/ 0000-0003-3983-4494
}

Received on 06.09.2018, accepted after revision on 19.10.2018

DOI: 10.31493/tit1812.0103

\begin{abstract}
The notion of a harmonious light environment involves the execution of a variety of sos-free functions. First of all, it is the creation of comfortable living conditions for people, which is to ensure the safety of traffic and pedestrians and the holistic perception of city accounting in the dark period of time. The provision of light comfort in the evening and at night is achieved on the basis of rationally selected quantitative and qualitative characteristics of artificial lighting, which are regulated by the norms.

Use of territories under the car-care center is used by special measures for engineering improvement. This makes it possible to create a high level of general and artistic and aesthetic perception of the objects of the city's car service.

Quality lightning is profitable. Since, the good lightning of the city reduces the number of injuries in an accident. The level of personal safety currently depends on the quality of lighting of courtyards, footpaths and playgrounds.

Information to enrich or change the emotional comfort of a person is possible with the help of the right color. The basis of the formation of architectural and urban light space play of colors of the light are solved by multiple tasks: there is a light floral environment, take into account the stakes and the transfer of the color from artificial light sources at night. It is not allowed color bright "separation", bright" failure", excessive brightness, which violates the unity of the composition. The quality of light delivery depends on the spectral composition of the light source, which determines its light transmission.

Lighting techniques are aimed at identifying the characteristics and effects of lighting. Lighting of
\end{abstract}

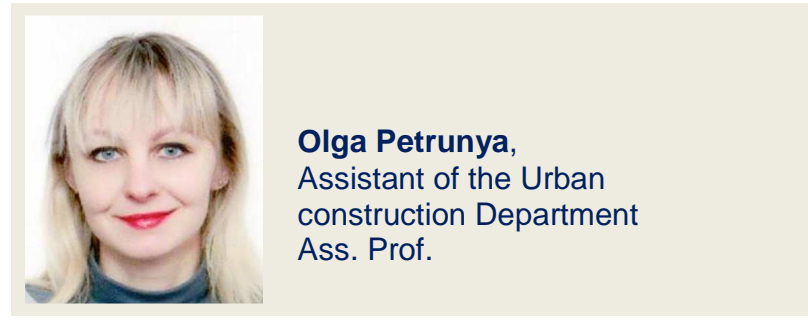

facades of buildings with general flood lighting should provide visibility of its decorative and plastic elements. The main requirement for the system of light ensembles of the city is-taking into account the visual perception of a person of the illuminated object in space.

Keywords: light, light gray deposit, objects and elements of the pavement, criteria of influence, measures for the engineering improvement of the city, objects of car service.

\section{INTRODUCTION}

Light is a powerful tool that allows you to discover the beauty of the world and emphasize the cultural and architectural value of the city.

Lighting equipment and technology must meet the requirements of energy saving, which provides for the optimization of constructive and energy parameters $[2,5]$. It is important to consider not individual objects or areas, and the whole complex of lighting systems areas, spaces, architectural and landscape objects in general. 


\section{MATERIALS AND METHODS}

The aim of the work is to identify the main criteria of influence on the lighting system of the modern city. Identify the types of modern artificial lighting. To study the process of lighting design for auto-salons and ways of their implementation.

The main criteria for the impact on the system of lighting the territory of the modern month include: visibility-provides normal conditions of visibility for drivers and pedestrians and the required level of quantitative and qualitative parameters of lighting, characterized by the current norms.

Security. Traffic safety in transport is ensured by the normal functioning of all components of this complex "man - vehicle - environment".

Meanwhile, the lack of reliability of the elements of this system (low discipline of traffic participants, poor technical condition of vehicles and roads) is the cause of road accidents and transport accidents $[1,2,6]$. Quality lightning is profitable. Since, the good lightning of the city reduces the number of injuries in an accident. The level of personal safety currently depends on the quality of lighting of courtyards, footpaths and playgrounds.

Economics. The factor of decision-making. The ability to create a quality lighting device at minimal cost. In practice, in the process of operation and repair of cheap lighting can require significant costs, compared to expensive. Therefore the characteristic of comfort of the light environment of the city is carried out by the most economic way in the presence of the choice of technical means for its providing.

Aesthetics. Modern society requires the lighting not only to perform

functional tasks, but also compliance with modern requirements of a harmonious world environment. There is a variety of outdoor lighting facilities of the city (streets, squares, open spaces, gas stations, service stations, transport interchanges, facades, etc.). Aesthetics should be combined with the real possibilities of society, contribute to the formation of visual comfort and visual and artistic specificity in the city.
Social life. Good lighting has a positive impact on such aspects of the social life of the city as trade, tourism, sports; creates a favorable psychological climate; has a biological impact on the human body; is the basis for a more open and active lifestyle.

To create the concept of a comfortable light environment of the city, a number of other factors are needed: the scale of the city, its functional zones; public centers; features of landscaping; the system of highways and maintenance. For each city characteristics of typical its lighting concept, which brings together external, architectural, accessory, advertising types of lighting $[2,4,7]$.

There are the following types of permanent lighting systems:

- for street lighting (providing lighting necessary for the safety of traffic and pedestrians);

- for architectural and artistic development (creation of light architecture of the city in the evening with the identification of the most valuable architectural, historical and artistic buildings, structures, monuments, fountains, etc., as well as entire complexes);

- for advertising lighting (information the population of trade, household and cultural news, window dressing mA-shops, kiosks, etc.);

- for light signals (indicators pedestrians driving directions, locations, stops, crossings, etc.) $[3,4,8]$.

Information to enrich or change the emotional comfort of a person is possible with the help of the right color. The basis of the formation of architectural and urban light space play of colors of the light are solved by multiple tasks: there is a light floral environment, take into account the stakes and the transfer of the color from artificial light sources at night. It is not allowed color bright "separation", bright" failure", excessive brightness, which violates the unity of the composition. The quality of light delivery depends on the spectral composition of the light source, which determines its light transmission $[2,6]$.

Modern artificial lighting is divided into types: decorative, architectural (total flood, local-gradient (fragmentary) lighting of the façade, hidden, projection (facades that glow), 
silhouette, contour, upper (multiple, ordinary light, lighting the top), landscape (step-by-step lighting, marking, sliding, flood, shading), lighting schedule, illumination (the light show, performance, temporary story, multimedia projects, laser scenography), static and dynamic color.

Architectural lighting is a direction of lighting design, engaged in artistic illumination of facades of buildings. By means of correctly executed architectural illumination it is possible to emphasize art features of the building, distinct elements (bas-reliefs, columns, windows, platbands), etc., to give it a beautiful esthetic look at night, to make dominating among other surrounding objects [8,9]. Before architectural lighting, there are a number of requirements: a variety of possible lighting effects; ease of maintenance and operation of architectural lights; electrical safety and protection of equipment from the effects of natural conditions; orientation; efficiency.

There are certain types of lighting: normalized (daily), emergency, periodic and festive. The choice of the type of lighting depends on the urban situation, the nature of the object, its purpose, especially the placement of lighting equipment, the creative design of the architect $[2,10]$.

\section{STARTING POSITION \\ URBAN-ECO-PHYSICAL PARALLELS}

Lighting techniques (selection of lighting equipment, their placement and possible ways of transformation, relationship, etc.) are aimed at identifying the characteristics and effects of lighting. Lighting of facades of buildings with general flood lighting should provide visibility of its decorative and plastic elements. This is achieved through a combination between the lighting and shadow zones (Fig.1). It is recommended to illuminate small diameter volumes with spotlights at a long distance. To identify the nature of multi-faceted objects lighting sources should be placed asymmetrically. There are three main ways of illumination of buildings and structures: local; lighting fill type; hidden architectural illumination of buildings.

1. Local illumination-illumination of the most interesting and bright parts of the structure. This effect is achieved by fixing special spotlights on the facade.

2. General filling of the facade with light. It is used to illuminate historical architectural structures or on the facades of buildings. Powerful spotlights illuminate the object in the selected color scheme.

3. Hidden architectural lighting. With the help of a light source creates its own pattern,

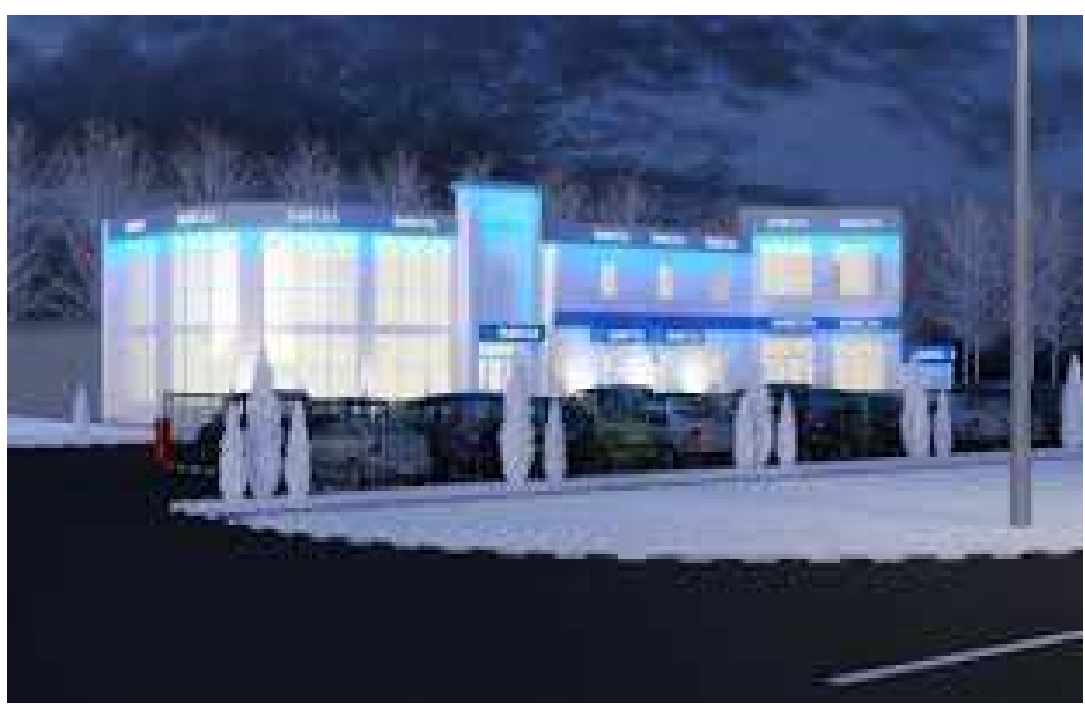

Fig.1. Lighting of the façade of the car service by way of creating a light contrast be tween the evening appearance of the given controversy and the surrounding landscape 
which makes it possible to both emphasize and change the appearance of the architectural forms of the building. Choosing one of the listed methods of illumination it is necessary to consider features of architecture of the building and its color scale.

Contour illumination is used during the holidays when illuminating the squares and streets of the city with mass illumination of buildings, monuments, bridges and fountains. In the building sometimes emit more bright light some interesting and spectacular part of it. This contributes to the creation of light contrast within it, enhances the overall impression of the evening view of the building and the surrounding landscape (Fig.4) $[6,12]$.

\section{RESULTS AND EXPLANATIONS}

The problem of placement of light composition of the city is associated with the creation

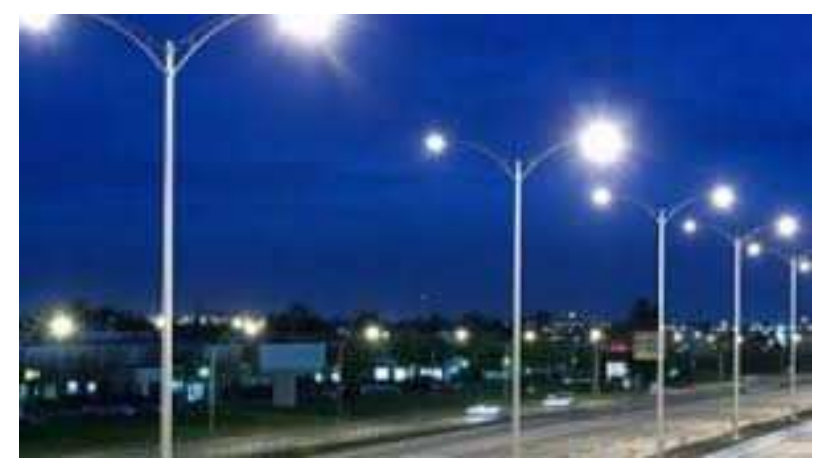

$a$

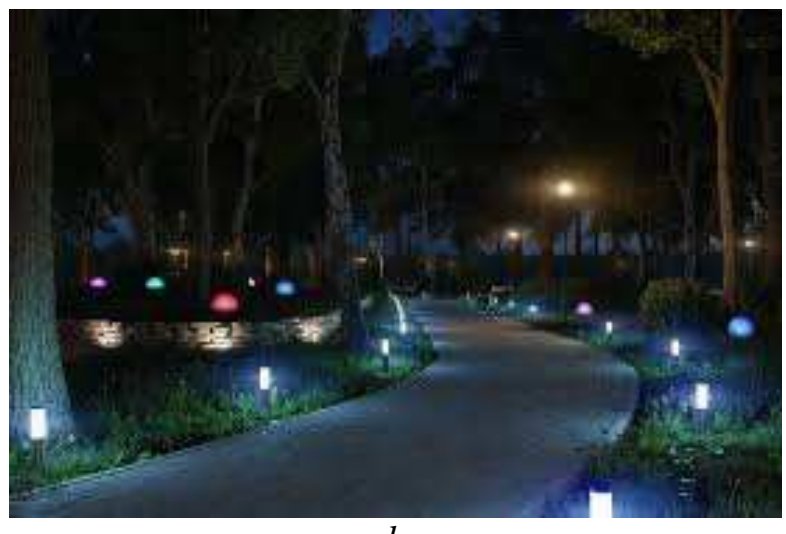

$b$

Fig.2. An example of the lighting of a transport magistral $(a)$, illustration of the street $(b)$ of light ensembles of different scales. At the same time, the light scale is a part of the architectural space, forming a single light architectural composition. The interaction of artificial light and architectural composition takes care in the following areas - space, volume, plastic and color. All this creates a light space, lightforms, light-plastic and light-color. The main requirement for the system of light ensembles of the city is-taking into account the visual perception of a person of the illuminated object in space $[1,15,16]$.

This approach makes it possible to illuminate the city, highlighting the main highways and the most important places, facilities and structures. Highways and streets stand out in cities in a special system, opposite the pedestrian - with clear spatial boundaries, special requirement trunk systems for $\mathrm{s}$ for the quantity and quality of light and light information (Figs.2, 3). All types of lighting systems work

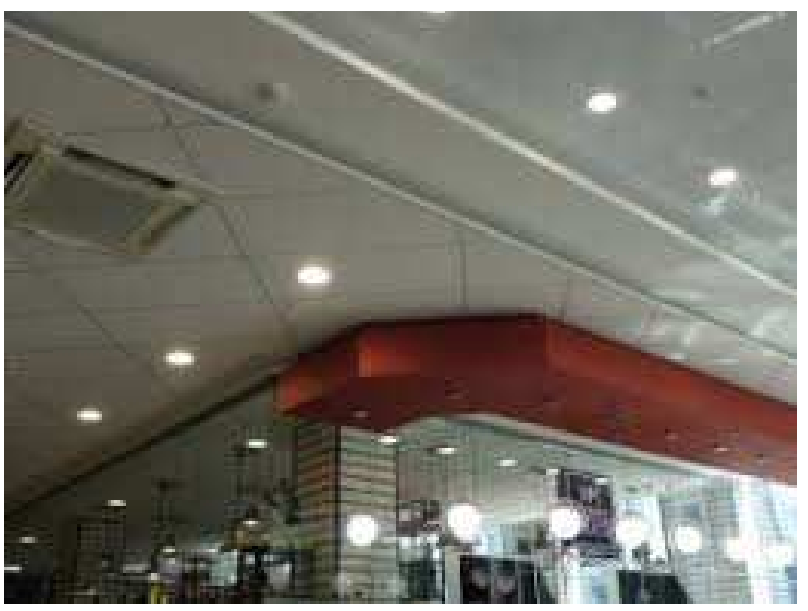

$a$

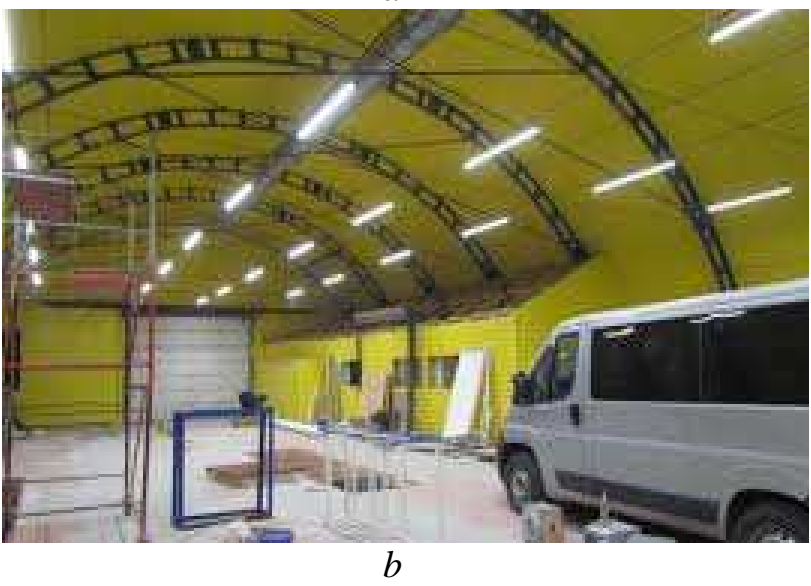

Fig.3. Examples of interior illumination of autolights ( $a$ - pendant lamps such as dome or bel, $b$ - trunk systems for linear luminaires) 
in cooperation with each other, taking into account the brightness of road surfaces of streets, squares and sidewalks, the brightness of showcases, light advertisements and lamps, as well as illuminated monuments and fountains, the degree of proximity that occurs in the field of view of a person. This takes into account the requirements of energy saving, operation, management of lighting systems according to the infrastructure of the modern city $[6,8,13]$.

Highways and streets stand out in the cities in a special system, opposite the pedestrianwith clear spatial boundaries, special requirements for the quantity and quality of light and light information.

Energy efficiency of lighting is influenced by the following factors: technological: availability of lamps, control systems, types of installation that can be used to reduce the power consumption of lighting systems compared to conventional practice.

- Economic: different methods of assessing the cost of the lighting system. The cost of the lighting system can be defined as the sum of capital costs and operating costs).

- Value: money, ecology, design.

- Perception: psychological evaluation of lighting. Level of visibility and visual comfort. Social status, health and appearance.

- Waiting: user's predictions about good lighting for each specific case $[2,14,16]$.

Architectural lighting of the facades of car showrooms is also important as well as internal lighting. It helps to attract the attention of many people and emphasize the features of the building.

Due to the sizes, types, optics, LEDs, as well as a wide range of lighting control, lamps-based LEDs can be used for general flood lighting (lighting of small architectural forms, contour illumination) and to create media facades of dynamic lighting, etc (Figs.4, 5). Such lamps have certain characteristics: efficiency, sustainability, to external influences and mechanical vibration loads; the minimum level of light pollution; the possibility of creating light paintings due to the possibility of light control [1, 17, 19].

Poorly adapted lighting conditions can include: the monotony of space; the impossi- bil

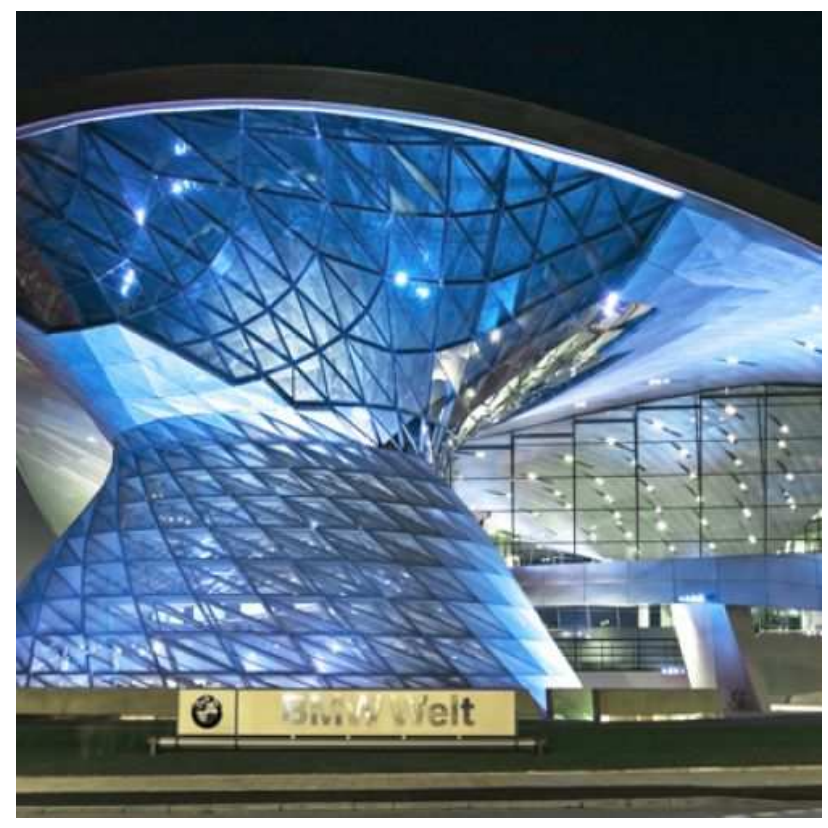

Fig.4. Lighting of the façade of the car service by way of creating a light contrast between the evening appearance of the given controversy and the surrounding landscape

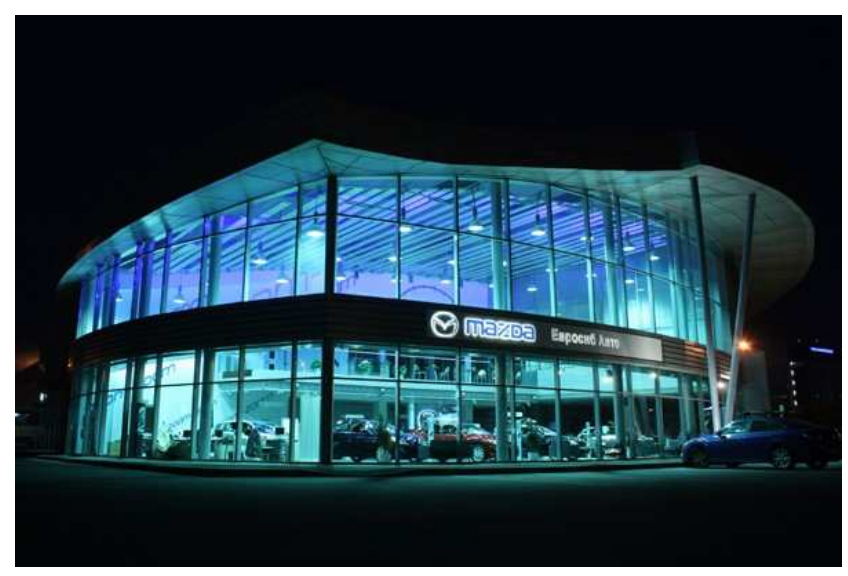

Fig.5. Lighting of glass facades inside line lanterns on the example Motor Show "Eurosib Mazda"

ity of safe orientation in space; the lack of eyecatching points, or vice versa, unnecessary attraction of attention; the use of finishing materials and their colors (which are poorly consistent with ambient lighting or even absorption of light), pale or aged in cool tones coloring the surrounding surfaces; failure to take into account energy consumption, excessive heat; 
high cost and inconvenience of maintenance; lamp design that does not fit into the situation, etc. $[18,20]$. All this violates the integrity of the architectural design of the city.

Therefore, to create a harmonious comfortable light urban environment complex combination of different lighting techniques and types of social functions, inscribed in the infrastructure of the modern city is important (Fig.6).

\section{CONCLUSIONS}

1. In today's world, thanks to the emergence of new technologies in the field of lighting, you can decorate the exterior of buildings as a whole, facades or parts of them; allocate certain buildings and their architectural features in the darkness of the night; provide a refined look.

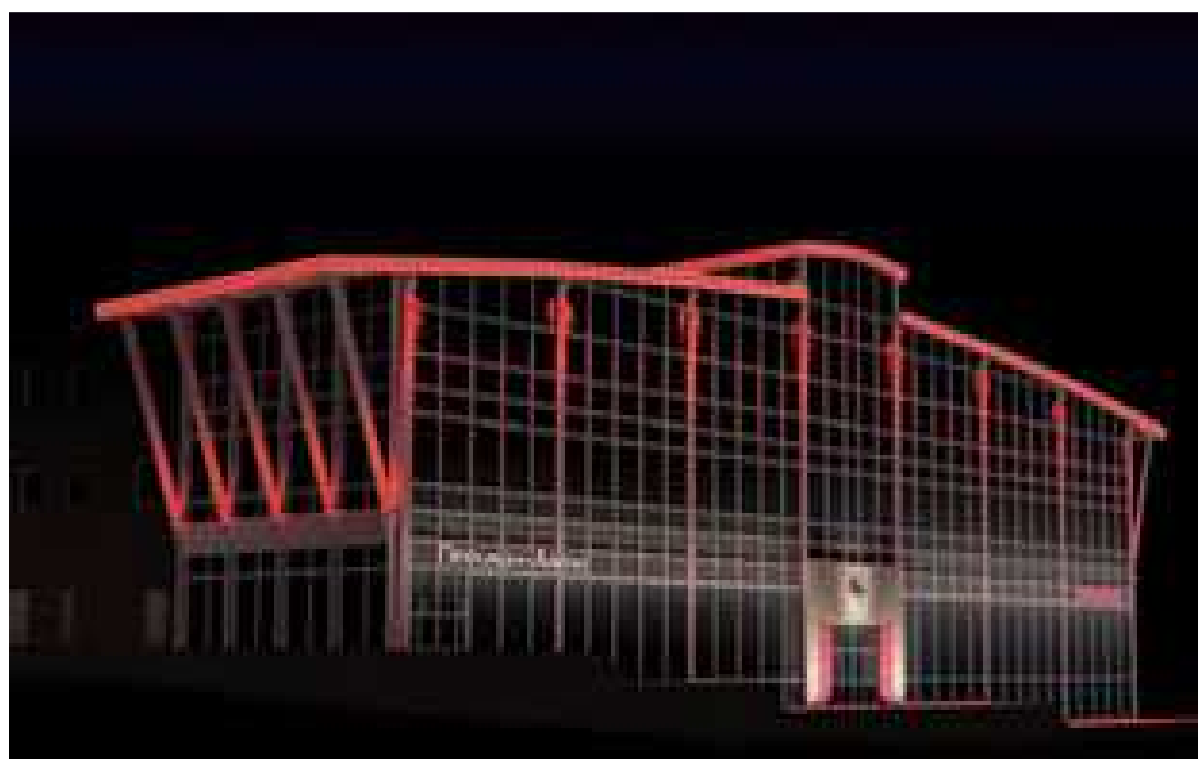

$a$

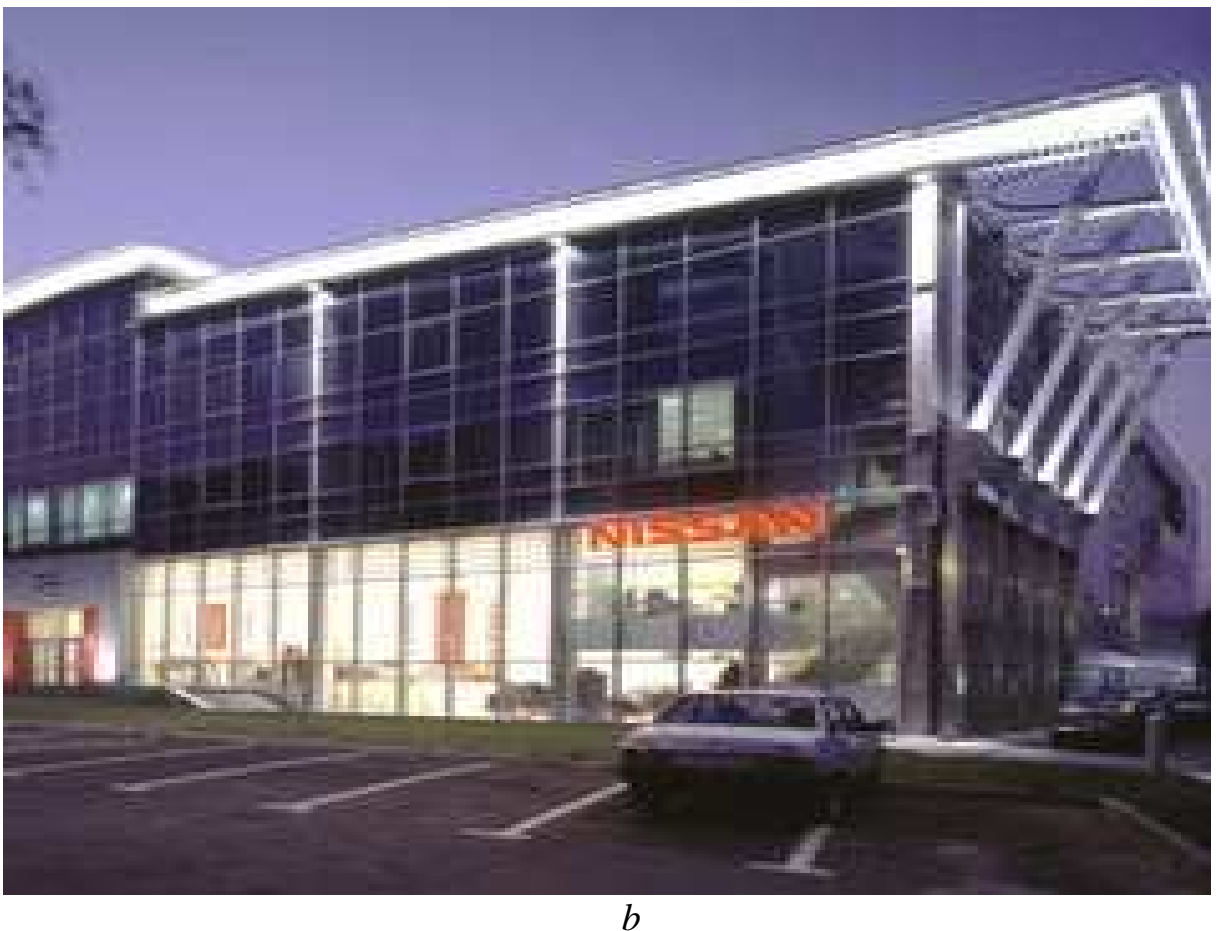

Fig.6. The option of lighting the car dealership Nissan brand: $a$ - an example of lighting the avosalona brand Nissan in red, $b$ - horizontal zone on the main facade, where the logo of the car dealership is lit white in color 
2. Properly designed lighting showrooms allow you to convey to the buyer the color of the corresponding car, as well as its appearance and increase sales.

3. The process of designing lighting for showrooms and their implementation is very specific since it requires the possession of certain knowledge and skills in the design of this direction.

\section{REFERENCES}

1. Mykolaivska I.A., 2006. Public welfare ofterritory. Moscow, Academy, 272 (in Russian).

2. Yargina S.N., Kositsky Ya.V., Vladimirov V. V., 1986. Fundamentals of the theory of urban planning. Moscow, Stroyizdat, 325 (in Russian).

3. SNiP 11-4-79б, 1980. Natural and artificial lighting. Entered since January 1, Moscow, 48 (in Russian).

4. CH II-4-79, 1991. Natural and artificial lighting. Norms of design. Moscow, Lighting, 1-31 (in Russian).

5. Ponomarev I.P., 1989. Engineering improvement of urban areas. Kyiv, UMK higher education, 124 (in Ukrainian).

6. Volotskoi N.V., Dadonov M.S., Mykolaic L.D., 1981. Lighting of open spaces. Leningrad, Energoizdat, 232 (in Russian).

7. Osietrin M.M., Petrunya O.M., 2003. Analysis of peculiarities of location and operation of service stations in Kyiv (on the example of Solomianskyi district). Urban planning and territorial planning. Scientific and technical collection Kyiv national University of construction and architecture. Iss.19, 263 (in Ukraine).

8. Matiash S., 1990. Man in town: Sociology Essays. Kyiv, Politizdat, 223 (in Ukraine).

9. DBN 360-92*, 1993. City building. Planning and construction of urban and rural settlements, Kyiv, Ukrarhnudinform, 107 (in Ukraine).

10. Yudin V.A., Samoilov D.S, 1975. City transport, Moscow, Stroyizdat, 287 (in Russian).

11.Sigiev A. V., 1972. Vehicles and city planning, Moscow, Stroyizdat, 22 (in Russian).

12.Markov O. D. 1998. Organization of AV service centers, Lviv, Oriiana Nova, 529 (in Ukraine.

13.Osietrin M., Dvorko O., 2016. A model for assessing the effectiveness of unregulated inter sections on the road network of Kyiv. Underwater technology, Vol.04, 100 ((in Ukraine).
14.Osietrin M., Bondar O., 2016. Urban planing experience in the implementation of the final principle of the organization of traffic on the approaches to bridges. Underwater technologies, Vol. 03, 82 (in Ukrainian).

15.Petrunya O.M., 2017. Ways of Considering Traditions when Forming the System of Maintenance in Ukraine. Underwater technologies, Vol. 07, 57-63 (in Ukrainian).

16. DBN V. 2.5 - 8 - 2006, 2006. Natural and artificial lighting. Engineering equipment of buildings and structures. Kyiv, Ministry of Construction, 96 (in Ukrainian).

17. JAGAN V. 2006. Illumination of objects/translation from Polish. Lviv, EcoInform, 42 (in Ukrainian). http://stroifaq.com

18.Shymko V.T., 2006. Architecturall-design engineering. Moscow, Art-architecture, 384 (in Russian).

19.Husev N. M., Makarevich V. G., 1973. Light architecture. Moscow, Stroiizdat, 137-106 (in Russian).

20. Keler V., Luckhardt V., 1961. Light in architecture. Moscow, Gosstroiizdat, 182 (in Russian).

\section{Значение и приемы освещения в автосервисе \\ Ольга Петруня}

Аннотация. Понятие гармоничная световая среда включает выполнение разнообразных социальных функций. В первую очередь - это создание комфортных условий проживания человека, что заключается в обеспечении безопасности движения транспорта и пешеходов и целостного восприятия образа города в темное время суток. Обеспечение светового комфорта достигается с помощью использования рационально выбранных количественных и качественных характеристик искусственного освещения, которое регламентируется нормами.

Использование территорий под автосервис проводится с помощью определенных мероприятий по инженерному благоустройству. Это дает возможность создавать на высоком уровне общее и художественно-эстетическое восприятие объектов автосервиса города. Качественное освещение выгодно. Так как, при хорошем освещении снижается количество травм при ДТП. Уровень собственной безопасности на данный период времени зависит от качества ос- 
вещения дворов, пешеходных дорожек и детский площадок.

Информационно украсить или изменить комфортное пространство вокруг человека можно с помощью правильно подобранного цвета. Формирование архитектурной и градостроительной световой среды выполняется игрой цвета. Таким образом решаются многочисленные задачи: создается световое окружение, учитывается цвет и передача цвета от искусственных источников света в ночное время. При этом не допускается цветовой яркий «отрыв», яркий «провал», безмерная яркость, которая нарушает единство композиции. Качество подачи света зависит спектрального состава источника света, который определяет его светопередачу. Приемы освещения направлены на выявления характерных особенностей та эффектов освещения. Освещение фасадов зданий общим заливным светом должно обеспечивать видимость его декоративно-пластичных элементов. Это достигается путем соединения между собой осветительных зон и теней. Главным требованием к системе световых ансамблей города является - использование зрительного восприятия человеком определенного объекта освещения в пространстве.

Ключевые слова: свет, световая среда, объекты и элементы благоустройства, факторы влияния, мероприятия по инженерному благоустройству города, объекты автосервиса. 